\title{
Property Rights as a Source for Identifying and Conserving the Spirit of Place
}

\author{
Mülkiyet Haklarının Yerin Ruhunun Tanımlanması ve \\ Korunması için Kaynak Olarak Kullanılması
}

Mert Nezih RifAiOĞLU, ${ }^{1}$ Neriman ŞAHIN GÜÇHAN²

\section{ABSTRACT}

Urban conservation has recently been held to possess a wide perspective for explicitly identifying and assessing the combination of tangible and intangible values of historic urban contexts, and implicitly defining and conserving authenticity, local identity and spirit of place through developments in assessment of values. This new way of understanding and appreciating historic urban context raises new questions for the urban conservation discipline. Discourses focus on the importance of developing reliable sources for investigating authenticity, identity and spirit of place in historic urban contexts. This paper outlines a theoretical approach to the spirit of place and proposes a new source; property rights as a contribution to the theory and practice of identifying and conserving the spirit of place through exploring human experiences, and as a way of forming, designing and constructing the urban form.

\section{ÖZET}

Kentsel koruma disiplini yerin ruhunun korunması üzerine odaklanmakta ve yerin ruhu kavramı tarihi kentsel bağlamı meydana getiren soyut ve somut tüm değerlerin birlikteliği ile tanımlamaktadır. Fenomenolojik bir olgu olan yerin ruhu kavramının kentsel koruma disiplininde tanımlanması ve korunması beraberinde yeni soruları ve araştırma konularını koruma gündemine getirmektedir. Kentsel ölçekte korunması gereken değerlerin tespitinde yerin ruhunu oluşturan parametrelerin tanımlanmasında kullanılacak kaynakların neler olabileceği henüz netleşmemiş önemli bir çalışma konusudur. Bu çalışma öncelikli olarak yerin ruhu kavramının kuramsal çerçevesini kent biçim çalışmaları, fenomenolojik araştrmalar ve kentsel koruma çalışmaları ışı̆̆ında inceleyip tanımlayacaktır. Ardından, ilk olarak bu çalışmada mülkiyet haklarının yerin ruhunun tanımlanmasına yönelik kaynak olarak kullanımı sorgulanacaktır. Bu çalışmada mülkiyet haklarının birinci derece güvenilir kaynak olarak tarihi kentsel bağlamı oluşturan somut ve soyut değerlerin birlikte korunmasına katkı sağlayabileceği vurgulanmaktadır.

'Department of Architecture, Mustafa Kemal University Faculty of Architecture, Antakya;

2Department of Architecture, Graduate Program in Restoration, Middle East Technical University Faculty of Architecture, Ankara, Turkey.

'Mustafa Kemal Üniversitesi, Mimarlık Fakültesi, Mimarlık Bölümü, Antakya;

${ }^{2}$ Orta Doğu Teknik Üniversitesi, Mimarlık Fakültesi, Mimarlık Bölümü, Restorasyon Lisansüstü Programı, Ankara.

Article arrival date: August 14, 2013 (Başvuru tarihi: 14 Ağustos 2013) - Accepted for publication: December 12, 2013 (Kabul tarihi: 12 Aralık 2013)

Correspondence (iletişim): Mert Nezih RiFAiOĞLU. e-mail (e-posta): mertnezih@gmail.com

○ 2013 Yıldız Teknik Üniversitesi Mimarlık Fakültesi - $\odot 2013$ Yıldız Technical University, Faculty of Architecture 
A rchitectural conservation is a comprehensive and mainly (technical) value-based decisionmaking process that involves a study of the past, present and future of cultural properties. In its contemporary meaning, conservation has evolved as a reaction to the destructive effects of industrialization in the later 19th century. Following the development of a conservation consciousness, especially after World War II, the scope of conservation evolved from an approach that dealt with the conservation of individual monuments to attempts at broader urban conservation "by considering the interrelationships of their physical forms, their spatial organization and connection, their natural features and settings, and their social, cultural and economic values". ${ }^{1}$

Inevitably, this evolution passed through various principles, manners, methods and techniques, led by guidelines and legal frameworks defined and applied for the conservation and management of cultural properties at both national and international levels.

On a parallel with the development of conservation approaches, from the identification of individual monuments to considerations of broader urban conservation, the definition of technical and socio-cultural values has broadened, from the study of tangible (material) attributes such as construction techniques, ornamentation, workmanship, typology and architectural elements, to take in intangible (immaterial) features such as tradition, language, customs, meaning, feeling and spirit (Figure 1). Related to these developments, urban conservation has a taken on a wide perspective, and by considering a combination of both the tangible and intangible aspects of urban contexts, defines and conserves the spirit of place. ${ }^{3}$

Many factors, including those related to the physical, socio-cultural, economic and administrative nature

\footnotetext{
UNESCO, 2011, para.5.

Rifaioğlu, M.N., Şahin Güçhan, N., 2007, pp.1099-1111. Rifaioğlu, M.N. Şahin Güçhan, N., 2008.

3 This attitude has been identified and updated through international conservation declarations and guidelines. For example, in 1994 the UNESCO Operational Guidelines for the Implementation of the World Heritage mentioned the importance of authenticity for groups of buildings or sites, aside from such tangible attributes as design, material, workmanship and setting (UNESCO, 1994, para 24). In 2005, intangible attributes were integrated into the guidelines in order to identify authenticity, spirit of place and identity for the definition of the outstanding universal values of cultural properties within their cultural context (UNESCO, 2005, para.49; Jokilehto, 2006). In 2008, the UNESCO Operational Guidelines for the Implementation of the World Heritage stressed the "importance of understanding the conditions of authenticity, identity, spirit of place in historic urban contexts if their cultural values are truthfully and credibly expressed through tangible and intangible attributes including: form and design; materials and substance; use and function; traditions, techniques and management systems; location and setting; language, and other forms of intangible heritage; spirit and feeling; and other internal and external factors" (UNESCO, 2008, para. 82).
}

of a historic urban context, such as natural elements, topography, townscape, pattern, order, culture, customs, uses, beliefs and traditions, need to be considered in the development of an understanding and appreciation. All of these combine to produce a distinctive tangible and intangible quality, helping to differentiate one place from another and create a distinctive spirit of place.

While urban conservation studies have sought rational solutions to investigating spirit of place and its hidden values in the historical urban context, the aim of this study is to outline a theoretical approach to the spirit of place and propose a new source; property rights as a contribution to the theory and practice of identifying and conserving the spirit of place through exploring human experiences and as a way of forming, designing and constructing the urban form.

This paper, therefore, dwells upon the importance of the three constant parameters of ownership, use and property rights' order in urban contexts in order both to investigate the dialectic links between the place and its inhabitants, and to define and conserve the combination of tangible and intangible values of the urban context that create spirit of place.

\section{The theory of Spirit of Place}

The spirit of (any) place is elusive. In phenomenological theory, it refers to a cluster of ideas about the place and its inhabitants in the diverse fields of geography, urban planning, urban design, architecture, sociology and environmental psychology; and concerns the meaning and significance of the place for its inhabitants and users. It is a subjective phenomenon that presents remarkable diversity in historic urban contexts, since it refers to the complex relationship between the physical environment and human experience. Consequently, the theory of spirit of place has emerged as an important subject in holistic urban conservation studies. In the scope of this enquiry, the concept of spirit of place has been theorized both in conservation discourses and studies of urban form.

As discussed earlier, in conservation discourse the primary focus has been on conserving authenticity, identity and spirit of place, something which is readily apparent in the charters and declarations of international conservation organizations. For example, the ICOMOS Nara Document ${ }^{4}$ declared that as the world is increasingly subjected to the forces of globalization and homogenization, defining authenticity becomes

\footnotetext{
4 ICOMOS, 1994.
} 


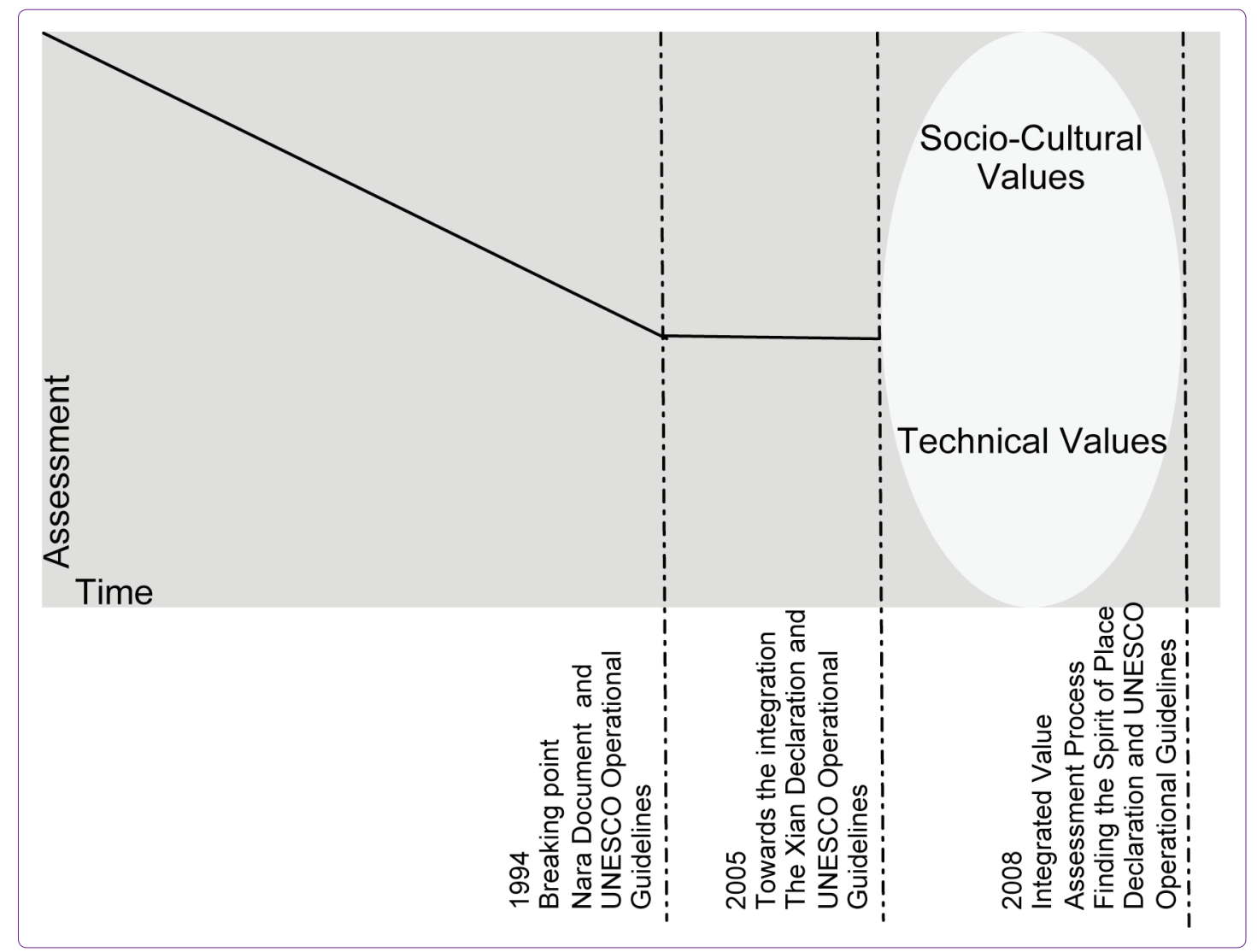

Figure 1. The change of assessment of values in urban conservation issue over time.

an important issue for the conservation of cultural heritage. The document also emphasizes the importance of defining and understanding cultural diversity, the search for cultural identity, and consideration of authenticity, all of which are essential in conservation practice.

The document defines social and cultural values as being vital features for understanding the unique tangible and intangible characteristics of every item of culture. Consequently, it underlines that no permanent or general decision can be an effective tool in the conservation of authenticity of cultural heritage, and it is thus not possible to base judgements of values and authenticity on fixed criteria. ${ }^{5}$

The Nara Document also suggests linking a wide range of information sources to ensure authenticity. These may include "form and design; materials and substance; use and function; traditions and techniques; location and setting; and spirit and feeling, and other internal and external factors". ${ }^{6}$ The use of these sources allows for the elaboration of specific artistic, historical, social, and scientific dimensions of a cultural heritage place.
Although a national document, the Australian ICOMOS Burra Charter ${ }^{7}$ offers another example of the principles to be applied for the conservation and management of cultural significance for cultural heritage places. The Charter is particularly significant for its definition of place, which it refers to as the "site, area, land, landscape, building or other work, group of buildings or other works, and may include components, contents, spaces and views". ${ }^{8}$ In addition, memorials, trees, gardens, parks, places of historical events, urban areas, towns, industrial places, archaeological sites, and spiritual places may also be included in the definition of a place. In this way, the Charter suggests that a place is formed according to its cultural significance, comprising aesthetic, historic, scientific, social and spiritual values, for past, present or future generations.

Consequently, the Burra Charter points out that places of cultural significance reflect the diversity of Australian communities, defining who they are and how their landscape has formed through the ages, and thus

\footnotetext{
5 ICOMOS, 1994, para.11. 7 ICOMOS, 1999.

6 ICOMOS, 1994, para.13. 8 ICOMOS, 1999.
} 
are irreplaceable and precious and must be conserved for present and future generations.

Another ICOMOS document, the Xian Declaration, ${ }^{9}$ stresses that both tangible -the setting and interaction with the natural environment- and intangible -social or spiritual practices, customs, traditional knowledge, use or activities- values contribute to the significance and distinctive character of a heritage structure. The Declaration also claims that heritage structures, sites or areas of various scales (historic cities, landscapes, seascapes, cultural routes and archaeological sites) owe their significance and distinctive character to their meaningful relationships with their physical, visual, spiritual and other cultural context and settings. ${ }^{10}$

The Xian Declaration stresses that documentation and interpretation of a setting should cover diverse contexts, and that its conservation and management should be carried out with the cooperation and awareness of local, interdisciplinary and international communities in order to understand the issues correctly and to make appropriate decisions regarding its significance.

Finally, in 2008, the ICOMOS Québec Declaration ${ }^{11}$ suggested a discussion and investigation of intangible cultural heritage and its relationship with tangible heritage, with the intention of developing new concepts, identifying potential threats and elaborating sound practices in the conservation and transmission of the spirit of place, defined as the tangible and intangible elements that give meaning, value and emotion to a place.

It was in the 1960s that the concept of identity -accepted as the starting concept of spirit of place- first appeared in urban studies. Kevin Lynch ${ }^{12}$ claimed that the image of the city has three components, always appearing together: identity, structure and meaning. He described identity as "the identification of an object, which implies its distinction from other things, its recognition as a separable entity. It is not in the sense of equality with something else, but with the meaning of individuality or oneness". ${ }^{13}$ Although, Lynch uses meaning as one component of the image of the city, he does not directly identify the spatial meanings of the city for its residents. ${ }^{14}$ His definition of 'identity' refers to the noticeable features of the city, while his use of the term 'structure' refers to the spatial relationships of those features.

\footnotetext{
9 ICOMOS, 2005.

${ }^{10}$ ICOMOS, 2005, para.4.

11 ICOMOS, 2008.

12 Lynch, K., 1960.
}

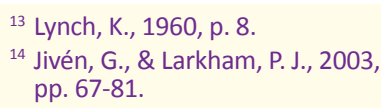

Following Lynch, others began to use the concept of "spirit of place" or "genius loci" allied to the concept of identity of a place. Spirit of place was widely held to be closely linked with the form and history of a place, requiring unique methods of approach in conservation activities. ${ }^{15}$ Following this, Conzen ${ }^{16}$ stressed that the quality and quantity of tangible cultural heritage, expressed through the accumulated historical form of towns and cities, was one main determinant of the character of a particular place, as the spirit of place. Conzen ${ }^{17}$ mentioned that the urban form, which arises out of societies' touch on the earth's surface, is accumulated and transformed through time to create a cultural landscape that is seen as an "objectivation of the spirit".

Accordingly, by the 1980s the spirit of place and identity were being considered as related to the tangible attributes of a town or a city, formed through historical processes. By that point, Christian Norberg-Schulz had developed ideas related to the psychology of architecture, ${ }^{18}$ and defined phenomenology in architecture as appropriate for understanding places and their meanings to local residents. He stressed that place means more than merely location, as there exists a 'spirit' which cannot adequately be described using analytical and/or scientific methods. He proposed a phenomenological method that would allow an understanding and description of the 'spirit' of the place through a depiction of its physical features and an interpretation of the human experiences within that place. It is important to recognize that Norberg-Schulz defines the spirit of place as a constitutive element in a town and city. Jivén and Larkham ${ }^{19}$ defined four thematic features in Norberg-Schulz's description of spirit of place:

- the topography of the earth's surface

- the cosmological light conditions and the sky as natural conditions

- buildings

- symbolic and existential meanings in the cultural landscape

From this, it is apparent that Norberg-Schulz had developed the earliest definition of spirit of place by including the consideration of symbolic and existential meanings in the cultural landscape. In philosophical discourse, 'existential' refers to the conditions of

\footnotetext{
${ }^{15}$ Conzen, M. R. G., 1966, pp.56-78. ${ }^{16}$ Conzen, M. R. G.,1975, p. 98.

Conzen, M. R. G.,1975, pp. 95-102. ${ }^{17}$ Conzen, M. R. G., 1966, pp.56-78.

Cullen, G., 1961.

Sharp, T., 1969.19 Jivén, G., \& Larkham, P. J., 2003,

Worskett, R., 1969.
} 
existence between the physical environment and the individual person by means of their emotions, actions, responsibilities, and thoughts. In this way, symbolic and existential meanings between the physical environment and its inhabitants become fundamental features for understanding the spirit of place.

On a parallel with Norberg-Schulz's work, Aldo Rossi brought a new perspective to arguments on the identity and spirit of place,,$^{20}$ naming the memory of a place for the citizen, as a fundamental feature of the city, as the locus solus. Locus solus refers both explicitly to the particular place with its tangible features, such as location, layout, form and texture; and implicitly to its intangible features, such as feelings, meanings and memory. From this perspective, the concept of locus solus is distinguishable from that of spirit of place in that it emphasizes an important relation within the place and takes into account temporal dimensions by referring to memory.

Following these developments, Lynch ${ }^{21}$ adapted his definition of identity and structure as given in The Image of the City (1960). He now classified identity and structure as the 'formal' components of sense, and described identity as "a sense of place", being the extent to which a person can recognize or recall a place as being distinct from other places; as having a vivid, or unique, or at least a particular, character of its own.

The definitions of identity, spirit of place and locus solus have been theorized in assessments of the logical and meaningful relations between concrete phenomena - the built form - and abstract symbolic and existential meanings - human experiences. Fundamentally, the main aim of the theory of spirit of place relies on subjective, hidden and dialectic relations such as rights, responsibilities, actions and thoughts between a 'place' and its 'inhabitants' in the urban context.

On a parallel with these theoretical developments, there has been growing interest in the practical implementation of the theory of spirit of place through phenomenological investigations in different disciplines, where the aim has been to uncover the substance of being and/or the substance of existence, and to follow the right intervention principles for the "intangible dynamics" of the "concrete phenomenon".

The wider perspective urban conservation issue brought about practices and discussions of the theory of spirit of place, not only to understand and appreciate human experience in relation to the historic physical en-

\footnotetext{
${ }^{20}$ Rossi, A., 1982, p.29.
}

${ }^{21}$ Lynch, K. 1987, p. 132. vironment, but also to define and conserve the specific and local values of the urban context. According to the theory of spirit of place, the holistic urban conservation approach should be able to define the substance of the historical urban context; the formation of the structure of the urban context and its interrelations; and the dialectic links between the context and its inhabitants.

This new way of understanding and appreciating historical urban contexts brings to the fore new questions and a broad range of discussions in the study and practice of urban conservation. One major focus for discussion is the reliability of phenomenological investigations for steering urban conservation decision-making processes.

\section{Phenomenological Investigations}

Phenomenological investigations concentrate on the substance of being, as seen and narrated from the feelings, meanings, and view points of the individual. Environmental psychologists, philosophers, urban designers and sociologists, among others, have long been investigating spirit of place drawing upon phenomenological means of understanding. Nevertheless, there has been significant debate on how human beings, who are limited to their own experiences of the place, can relate both to each other and to the context. ${ }^{22}$ Asa Briggs' opinion on the subject was that;

When you start thinking about the sense of place, you have to bear in mind that the same place means quite different things to different people, according to where they live in it. If you lived in the East of London in the nineteenth century, you had very little contact with the West End, and vice versa. ${ }^{23}$

Closely related to this debate, the phenomenological investigation into the poetic image of the house by Gaston Bachelard, ${ }^{24}$ one of Europe's leading philosophers, is still hotly debated. According to Bachelard, the poetic image is "a sudden salience on the surface of the psyche" and "it has an entity and a dynamism of its own; it is referable to a direct ontology", ${ }^{25}$ which means it cannot be understood rationally, but only through phenomenological investigations. ${ }^{26}$ Bachelard claims that: "A house that has been experienced is not an inert box. Inhabited space transcends geometrical space", ${ }^{27}$ defining the house as a privileged entity and suggesting that understanding the intimate values of the house needs new tools and approaches. He stresses that a "phenomenological study of the house, pro-

\footnotetext{
${ }^{22}$ Madanipour, A., 2003.

${ }^{23}$ Briggs, A., 1975, p. 691.

${ }^{24}$ Bachelard, G., 1994.
}

${ }^{25}$ Bachelard, G., 1994, p.xvi.

${ }^{26}$ Madanipour, A., p. 73.

${ }^{27}$ Bachelard, G., 1994., p. 47. 
vides to integrate all the special values in one fundamental value". ${ }^{28}$ In using this approach, he aims to go beyond the scope of analytical architectural investigations by reading the house or reading the room when attempting to define the spirit of the house.

Just as with other phenomenological investigations, Bachelard aims to explore the intimate values of the house that cannot be defined and understood through analytical architectural investigations. Nevertheless, many uncertainties underlie Bachelard's phenomenological investigation of the house. He investigates the narratives of a user that was born and raised in the same house, with no experience of any other houses. Clearly, in contemporary society intimate values have undergone constant change, from stabile to much more mobile residents.

The major criticism of this perspective is based on the validity of phenomenological investigations in dynamic, variable uses of urban scales rather than a constant use of a single building scale.

The fact that there are different interpretations and meanings of space in the urban context, as different groups give different meanings to a context, as it becomes a multi-layered place, reflects the way that places are socially constructed. ${ }^{29}$ Therefore, investigating the values of the urban context from individuals' narratives and viewpoints may result in limited and subjective values. In the conservation context, making decisions based on subjective values can result in a delusion, going against one of the main aims of urban conservation studies, which is to conserve the real, objective and fundamental characteristic values of the context and sustain the lifestyles and cultures of places, avoiding subjective decisions and preventing places from becoming a spectacle for visitors.

Under these circumstances, if the spirit of place is closely bound to the look of things, and the scale is considered as urban, then the following questions can still be deemed relevant in urban conservation;

- How can a phenomenological approach identify the intimate values of the urban context that cannot be defined and understood through analytical urban conservation investigations?

- How can experts (ie 'outsiders') observe the urban context and realize the intimate values of the residents that lie hidden in the urban form?

- How can the phenomenological method allow an

\footnotetext{
${ }^{28}$ Bachelard, G., 1994, p.3. $\quad{ }^{29}$ Knox, P., 1995
}

understanding and description of the 'spirit' of the context through a depiction of its physical features and an interpretation of the human experiences within that context?

These questions are encapsulated in Briggs's exclamation as a resident of a historic urban context;

What will people make of our own values in the future, when they look at us years and years from now - if they are in such a privileged position as to be able to do so? When we are relating the present and the future, the key role in making sure that future is yours, not mine. ${ }^{30}$

\section{Urban Conservation Studies}

Yet, as discussed previously, on an urban scale, investigating the spirit of place by understanding and identifying plural interpretations and meanings between the context and the users is a complex subject, and no widely-accepted methodology has yet been developed.

Accordingly, urban-scale conservation studies still face the question of what kind of investigations would help in understanding and identifying the values generated from human experiences within the physical context, or in other words, the spirit of place.

In fact, there have been many theoretical and practical studies on this issue that may provide some answers for the field of urban studies. As a theoretical example, Karl Kropf defined the basic investigation principles in the built form derived from Johann Wolfgang von Goethe, and applied by Gianfranco Caniggia and M.R.G. Conzen.

According to Kropf, the urban context should be investigated in terms of human choices, process of formation, arrangements of parts and as a whole, and an interpretation. Kropf defined the human choices as tangible attributes - stone, brick, timber, glass, tile, etc. - and how they are put to use by humans. He noted, "(The) built form is the material in an arrangement which is the result of human choice, the choice of using a particular material for a particular purpose and putting it in a particular place". ${ }^{31}$ From an urban conservation point of view, an assessment of human choices in the built form would allow a definition of the technical values of the context.

Another investigation aspect, the process of formation, is defined as the concrete phenomenon for understanding and appreciating the sequence of events

\footnotetext{
30 Briggs, A., 1975, p. 695.
} 
and acts of buildings which have formed the context throughout history. In urban conservation studies, it would refer to the historical and socio-cultural values of the context. The arrangement of parts is another matter for investigation, being important for understanding the interrelation between individual parts, and between the individual parts and the whole. Such an investigation method would be appropriate for investigating the physical and morphological values of the context in urban conservation studies.

Finally, Kropf discusses the issue of interpretation, which is proposed for investigating the vague aspects of the sense of built environment by understanding "the forms which contribute to a whole and make the means of identifying those forms identifiable and repeatable". ${ }^{32}$ This method refers directly to the tangible architectural features of the context, and would allow the architectural and typological orders and/or values of the urban context to be determined.

Although interpretation is the key means of understanding the sense of built environment, Kropf leav[es] aside the ontological meanings of the object and aims to understand and identify the repeatable forms of the context in an assessment of the sense of built environment. The logic of his aim relies on addressing the problems faced in ontological investigations which may define subjective, expert's and/or observer's own viewpoints and values.

Essentially, urban conservation studies are almost wholly driven by the expert, and all values identified in the analysis are given by experts. Accordingly, their roles and values can be held up to criticism, since urban forms result from different value systems and shape different identities for different groups.

Yet in most national conservation systems, it is the experts who observe the historic urban context, using objective tools so as to designate and conserve a very delicate and subjective subject, the spirit of built environment. It is important to find the intimate, hidden, unidentified, subjective values of the context through the use of objective tools and methods created over time between the physical urban context and the experiences of different social groups, occupants and users.

Urban conservation studies normally seek to assess the character of the built environment through typological, morphological and architectural analysis. Nevertheless, although the identity of an area may

${ }^{32}$ Kropf, K.S., 1993, p.11. persist through time, spirit of place can change as its inhabitancy or users change. This leads to the question: How can experts understand the spirit of place and define its continuity through observations and/or interpretations, since residents, ways and standards of living, physical structures, and the overall socio-cultural context all change over time?

This is an important subject, both theoretically and practically, yet difficult to address in urban conservation studies; and after a decade of searching, still the right tools have yet to be found for understanding and conserving the very delicate subject of spirit of place and its comprehensible meanings from tangible features to intangible ones.

As Pendlebury stated; “...conservation as a practice needs to evolve reflexively; it needs to embrace new understandings of the social role of heritage and its conservation, while retaining and sustaining many of its core principles. This is a difficult challenge". ${ }^{33}$

\section{Property Rights as a Source to Identify Spirit of Place}

Ownership is an important aspect when considering how inhabitants create an urban pattern from an urban context, being the starting point of living, using, building, designing and forming the built environment. It is accepted as the substance regulating urban context and defining its character. Ownership can refer to the physical forms, socio-cultural structures, administrative issues, and political and economic conditions of the urban context, and their way of defining an order between the context and its inhabitancy. As Suraiya Faroqhi states;

The urban societies of Ankara and Kayseri consisted essentially of house owners, while on the other hand, it would appear that people do make significant statements about their culture by the way in which they arrange their houses-if only we knew how to decode these statements. ${ }^{34}$

In addition, ownership relates strongly to the existential meanings of urban context, being defined as "the existential foothold of appropriators". ${ }^{35}$

Moreover, ownership is a legal right over tangible and intangible properties and forms logical -meaningful- beneficial relations between the object and its owner. It is a fact that an object becomes more valuable when one owns it; more meaningful when one uses it;

\footnotetext{
${ }_{33}$ Pendlebury, J., 2009, p.13.

${ }^{34}$ Faroqhi, S., 1987, p.5.
} 
and more beneficial when one has rights to it, referring explicitly the terrestrial relationships, and intrinsically to the spiritual relationships between the human and the object. Hence, ownership would indicate something beyond the existence, beyond the apparent, beyond the known, beyond the man-made settlement boundaries, beyond life and the realm of the senses between the owners and the socio-spatial phenomenon of the city which creates spirit of place.

The three constant parameters of ownership, use and property rights in urban contexts are dwelt upon in this study and can be expanded upon as follows:

- Use: Refers to the use of built environment independent from the building categories. Use is closely related to the special use principles occurring between inhabitants and buildings, streets, public and private urban spaces. It aims to define the esoteric relations in the use of the urban context.

- Ownership: Refers to social life and its order within the urban context by analyzing the owner's identity information. The ownership parameter helps in the development of an understanding of social networks and their relations with the built environment.

- Property Rights: Refers to user and ownership rights that affect both the tangible and intangible aspects of the urban context, and creates different user investigations and experiences on both urban and neighbouring scales.

The relationships between ownership, use, property rights and the physical form can be seen and appreciated in societies of pluralist democracies, or in societies of socialist or communist countries, when analyzing not only related laws and judgments, but also the urban form and socio-cultural context. Therefore, they would be able to refer major aspects of urban context by the variety of property rights such as possess, use, assignment, beneficial and dispose, and accordingly, can be investigated in the urban context and referred to tangible and intangible features of the context

Possess refers directly to the identity of the owner of the geography in question, such as river, rivermouth, lake, landscape; streets, whether public or private; territory; buildings and architectural elements such as common walls, doors, etc., but may also refer to the intangible features of the context. It has a primary relation with agreements between owners; and secondary links with the spiritual relations and meanings between the owner and the context. For example, the owner of a building may be a religious charitable foundation, and so the building would have a special spiritual meaning for the inhabitants.

Use has primary relations with both the tangible and intangible features of the context. In some cases it is specified by law, and in others by social systems. For example, the United Kingdom's Rights of Way Act of 1932 and the Highways Act of 1959 are examples of how use and context may be experienced by the inhabitants (Figure 2a, b; 3a, b).

In contrast, cul-de-sacs are used in Middle Eastern societies, which have multi-cultural, introverted social forms and organic urban contexts, have been organized around a social mechanism (Figure 4a, b).

Parts of the urban context may be assigned for spe-

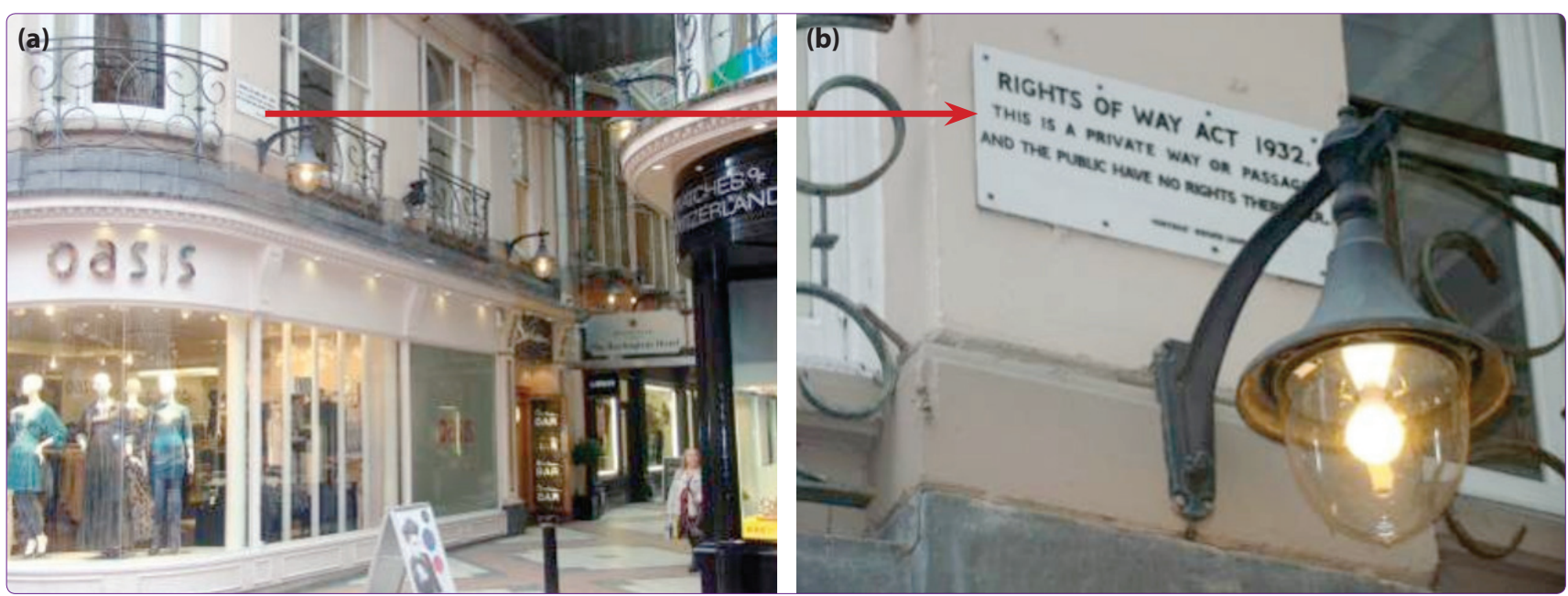

Figure 2. (a) A passage at New Street, Birmingham, United Kingdom (Photograph: Rifaioğlu, M.N., 2010). (b) The inscription panel relates to rights of way. It states; Rights of way act 1932: This is a private way or passage and the public have no rights there over (Photograph: Rifaioğlu, M.N., 2010). 


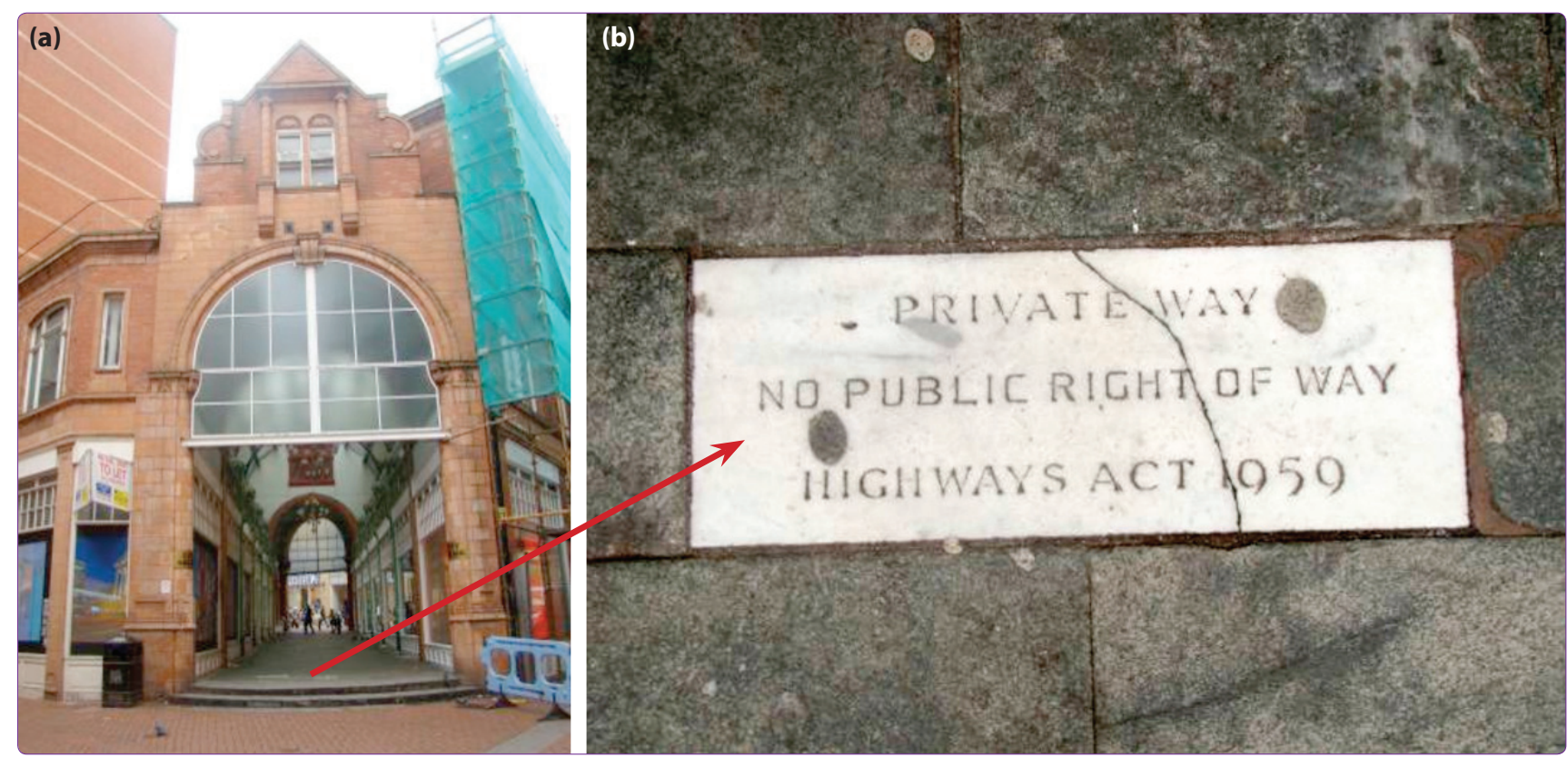

Figure 3. (a) The city arcade, Birmingham, United Kingdom (Photograph: Rifaioğlu, M.N., 2010). (b) The inscription panel is located on the ground floor of a city arcade (Photograph: Rifaioğlu, M.N., 2010).
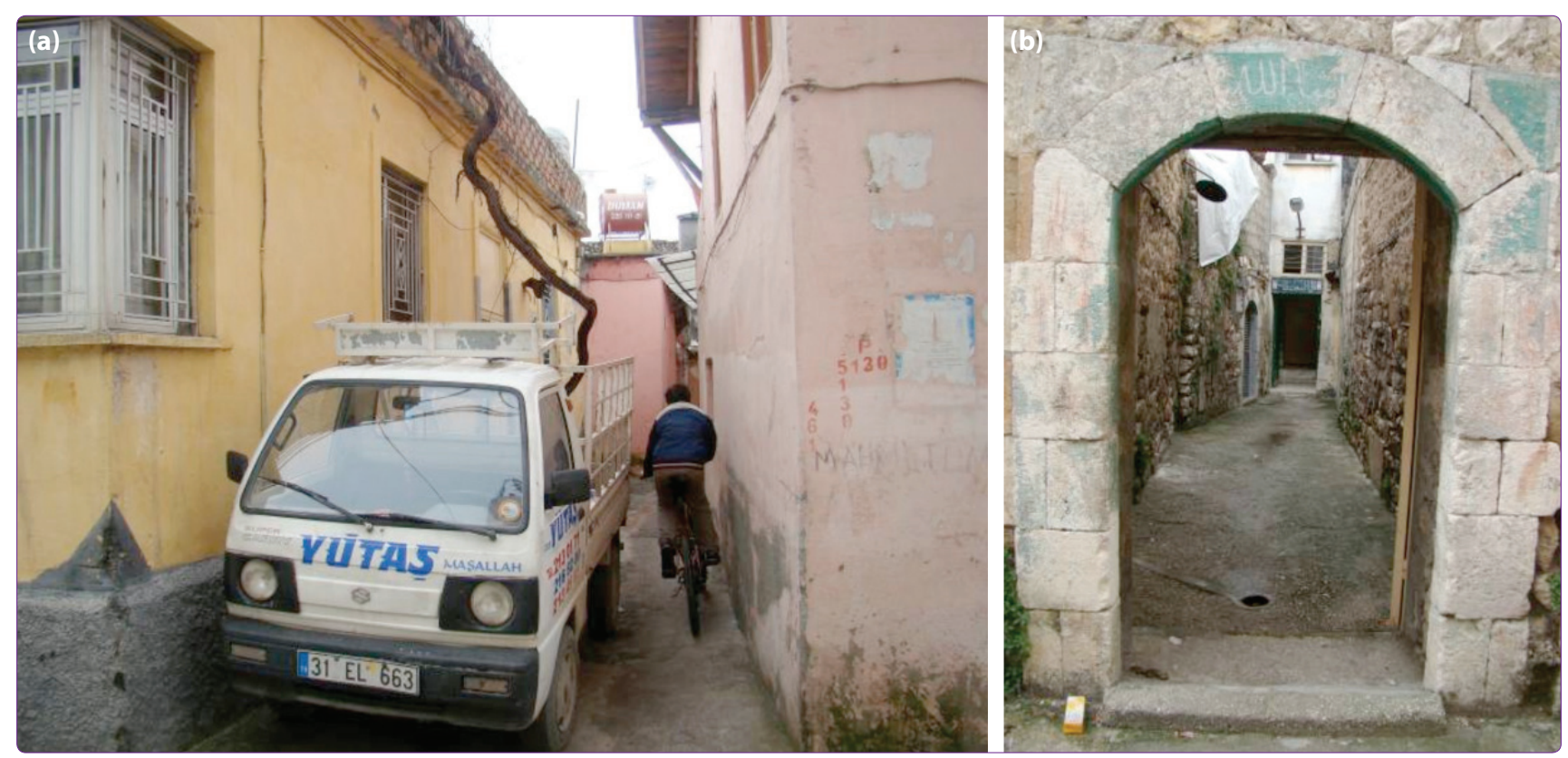

Figure 4. (a, b) Two different way of using a cul-de-sac in Antakya (Photograph: Rifaioğlu, M.N., 2009).

cific use. For example, a building can be assigned for inhabitants' use, or a street can serve different purposes according to its assignment. According to the aim and the content of the assignment, the inhabitants use the urban context for different purposes, resulting in intangible values (Figure 5a, b; 6a, b).

A direct relationship between the tangible and intangible features of the context is beneficial, and is referred to as "beneficial owner" in which the owner is entitled to the possession and use of the land or its income for his own benefit under the law of property. ${ }^{36}$ In some circumstances property owners have to open up their property incomes or architectural and/or spatial features for use by beneficial owners. For example, in Middle Eastern societies the waqf institution plays a key role in assigning the income of a building or area of

\footnotetext{
${ }^{36}$ Jonathan Law and Elizabeth A. Martin, 2009.
} 

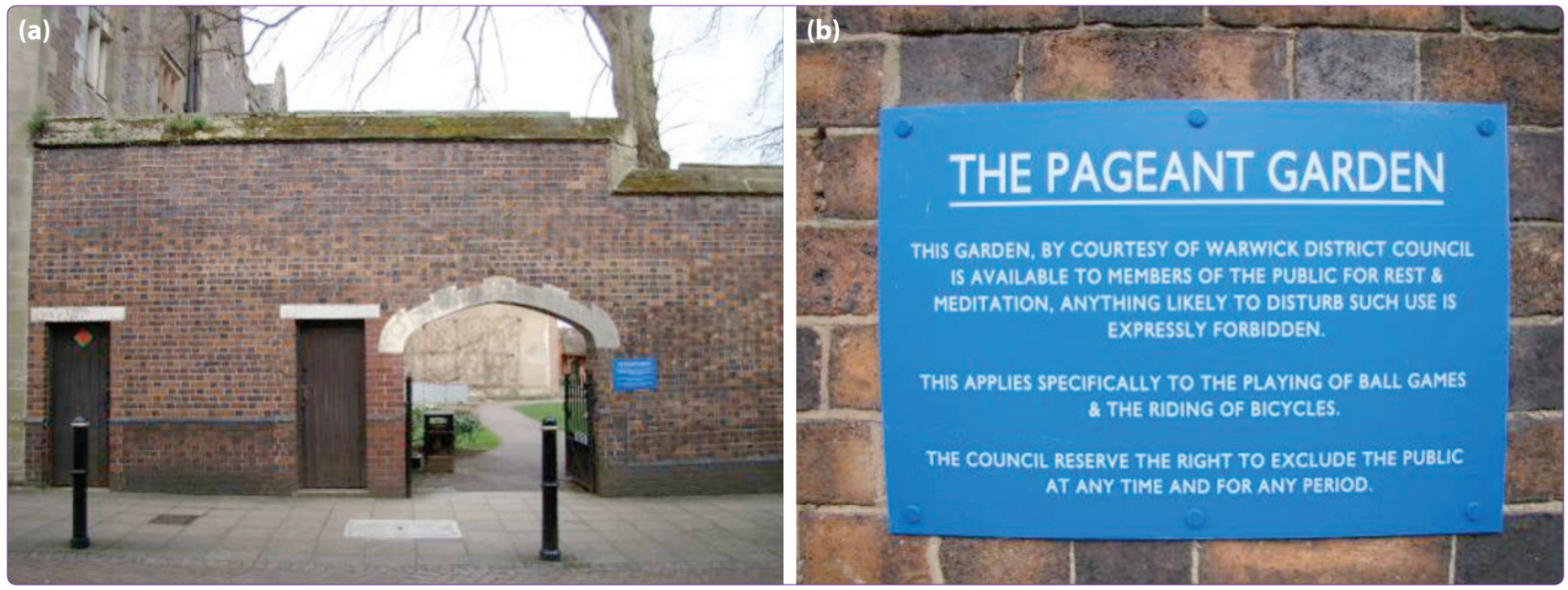

Figure 5. (a) The Pageant Garden street entrance, Warwick, Warwickshire, United Kingdom (Photograph: Rifaioğlu, M.N., 2010). (b) The inscription panel on the assignment of the Pageant Garden. It states; this garden by courtesy of Warwick District Council is available to members of the public for rest and meditation. Anything likely to disturb such use is expressly forbidden (Photograph: Rifaioğlu, M.N., 2010).
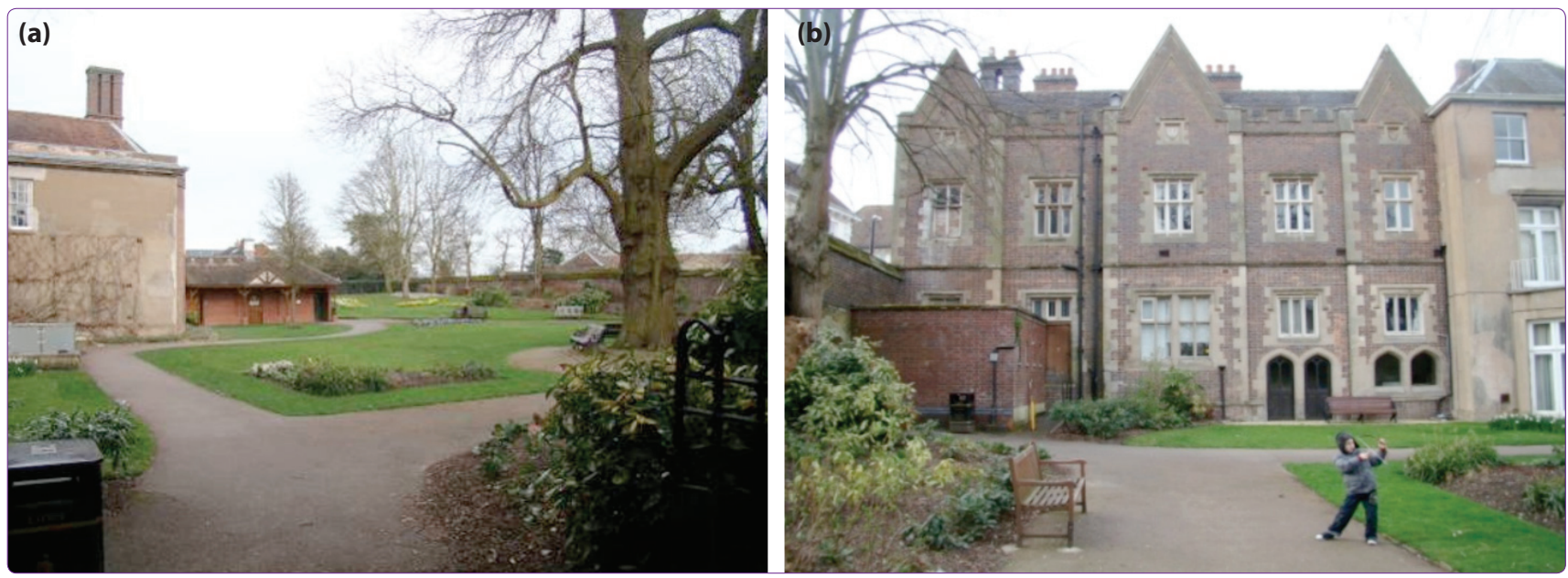

Figure 6. (a) The Pageant Garden, Warwick, Warwickshire, United Kingdom (Photograph: Rifaioğlu, M.N., 2010). (b) The Pageant Garden and its surrounding buildings, Warwick, Warwickshire, United Kingdom (Photograph: Rifaioğlu, M.N., 2010 ).

land to the poor people of society. This benefit approach can affect the entire urban context, as every single entity has an owner, while use of the context brings beneficial rights to the users. This may refer to morals, meanings, agreements and spiritual aspects, as well as all tangible aspects of the context (Figure $7 a, b$ ).

Dispose has secondary relations with buildings and primary relations with morals, meanings and agreements. The best example of this category can be found in the case of charitable buildings. In every society, charitable foundations have special meaning for the inhabitants, in that they help people, providing care and disposing their utilities.
The analysis of the three constant parameters has identified an intersection between "analytic architectural" and "phenomenological investigations" through a "reading of the context" of property rights.

\section{Conclusions}

The issue of urban conservation has begun take on a wide and holistic perspective, aiming to practice and discuss the theory of spirit of place, in order not only to understand and appreciate human experiences in relation to the historical physical environment, but also to define and conserve the intimate and custombased values of the urban context. 

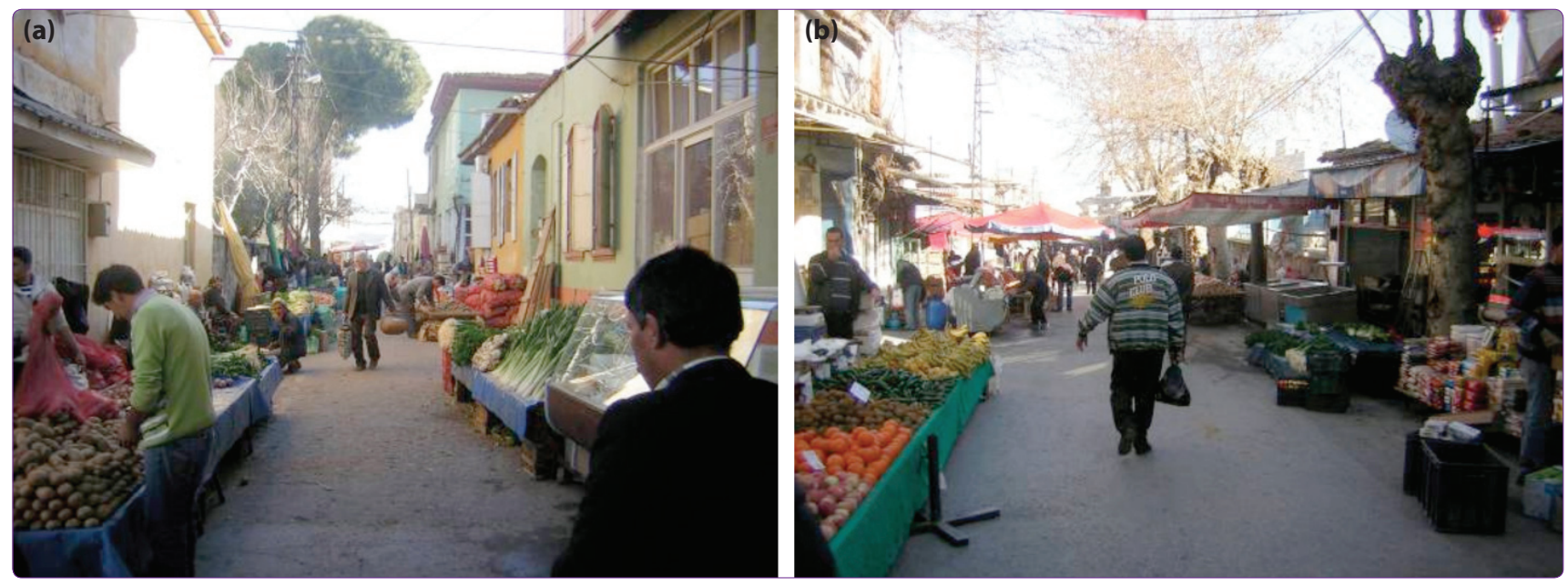

Figure 7. (a) Bazaar is set up every Thursday in the urban core of Tire (Photograph: Rifaioğlu, M.N., 2008) (b) Beneficial use of the public street. Traditional "Thursday bazaar" in Tire, İzmir-Turkey (Photograph: Rifaioğlu, M.N., 2008).

Accordingly, it creates a dilemma centred on how urban conservation studies are able to define the substance of the historical urban context; the formation of the structure of the urban context and its interrelations; and dialectic links between context and its inhabitants, since the theory of spirit of place is reliant upon the subjective, hidden and dialectic relations, such as rights, responsibilities, actions and thoughts, between a "place" and its "inhabitants".

Urban conservation studies are faced with a need to integrate subjective theory into their well-designed analytical investigation methods of urban contexts, which aim traditionally at defining objective values and decisions. It is not possible to overcome this problem through definitions of only the intangible values of the historical urban context, because the theory requires deductive and inductive inferences into the way urban contexts are formed, designed, inhabited and used by their inhabitants. In conservation studies, this has been a difficult subject to address, both theoretically and practically, and after a decade of searching, the discipline has yet to come up with the right tools for understanding and conserving the delicate subject of spirit of place and its comprehensible meanings, both tangible and intangible.

Scale is another important input in the assessment of urban contexts within the holistic urban conservation issue; and becomes more intricate and more difficult when dealing with urban-scale historical urban contexts rather than rural ones. This is because the parameters that form urban fabrics are much more complex than in rural cases, being exposed to many more interventions and/or transformations, both physically and socially. As a consequence, on an urban scale, the urban conservation issue needs a conceptually and contextually different and well-defined investigation method that evolves reflexively for defining the spirit of place, while at the same time retaining and sustaining its core principles.

This study proposes that ownership, use and property rights in an urban setting merit investigation in an attempt to define the invisible links and values that have emerged between the urban form and its inhabitants. This consideration of how an urban form is created and regulated according to ownership rights is a subject that to date has not been investigated in the urban conservation discipline.

It is the fact that, ownership is the starting-point of living, using, building, designing, and forming the built environment. It is a key aspect of regulating the urban context, and hence of defining and maintaining its character. Therefore, ownership can refer to physical forms, socio-cultural structures, administrative issues, political and economic conditions of the urban context and their way of defining an order between the urban form and its inhabitants, because it relates strongly to the existential meanings of the urban context.

The influence of ownership, use and property rights would help in defining the combination of tangible and intangible values of the urban context which create a significant historical urban context. Property rights are both important factors in the formation of urban form, and important aspects in identifying and conserving the dialectic links between inhabitants and the historical urban context which create a spirit of place. An investigation into the three constant parameters wo- 
uld create a well of knowledge on underlying, hidden aspects of forming the urban form of which current holistic urban conservation studies are in great need.

\section{References}

1. Bachelard, G., (1994), (originally 1958 in French), The Poetics of Space, Beacon Press, Boston, MA.

2. Briggs, A., (1975), "The Philosophy of Conservation", Royal Society of Arts Journal, London, United Kingdom.

3. Conzen, M.R.G., (1966), Historical townscapes in Britain: a problem in applied geography. In J. W. House (Ed.), Northern Geographical Essays in Honour of G.H.J. Daysh (pp. 56-78). Newcastle upon Tyne, England: Oriel Press.

4. Conzen, M.R.G., (1975), Geography and townscapes conservation. In H. Uhlig \& C. Lienau (Eds.), Anglo-German Symposium in Applied Geography (pp. 95-102).

5. Cullen, G., (1961), Townscape, London, Architectural Press.

6. Faroqhi, S., (1987), Men of Modest Substance House Owners and House Property in Seventeenth Century Ankara and Kayseri, Cambridge University Press.

7. Günay, B., (1999), Property Relations and Urban Space, METU Faculty of Architecture Press, Ankara.

8. ICOMOS (1994), The Nara Document on Authenticity, Retrieved from http://www.international. icomos.org/ charters/nara_e.htm

9. ICOMOS (1999), The Burra Charter (The Australia ICOMOS Charter for Places of Cultural Significance), Retrieved from http://australia.icomos.org/wp-content/uploads/BURRA-CHARTER-1999_charter-only.pdf

10. ICOMOS (2008), Québec Declaration on the Preservation of the Spirit of Place, http://www.international.icomos. org/quebec2008/quebec_declaration.pdf/GA16_Quebec_Declaration_Final_EN.pdf

11. Law, J, and Martin, E.A., (2009), A Dictionary of Law, Oxford University Press, United Kingdom. Retrieved from Birmingham City University Online Services,16 February 2010 http://www.oxfordreference.com/views/ENTRY. html?subview=Main\&entry=t49.e361

12. Jivén, G., Larkham, P. J., (2003), Sense of place, authenticity and character: a commentary, Journal of Urban Design, 8 (1), 67 - 81. Retrieved January 07, 2007, from EBSCOhost Academic Search Premier database.
13. Kropf, K.S., (1993), "An Enquiry into the Definition of Built Form in Urban Morphology", un-published PhD thesis, Department of Geography, University of Birmingham, vol.1, p. 10.

14. Lynch, K., (1960), The Image of The City. Cambridge, MA: MIT Press.

15. Lynch, K., (1987), Good City Form. Cambridge, MA: MIT Press.

16. Madanipour, A., (2003), Public and Private Spaces of the City, Routledge, New York.

17. Norberg-Schulz, C., (1963), Intentions in Architecture, Oslo, Universitetsforlaget. Also cited in Jivén, G., \& Larkham, P. J., 2003. Sense of place, authenticity and character: a commentary, Journal of Urban Design, 8 (1), 67 81.

18. Pendlebury, J., (2009), Conservation in the Age of Consensus, Routledge, New York.

19. Rifaioğlu, M.N., Şahin Güçhan, N. (2007), "The Concept of Identity and Its Identification Process in Urban Conservation Projects", An International Conference of CSAAR on Regional Architecture and Identity in the Age of Globalization, 13-15 November, Tunis, TUNISIA, pp.1099-111.

20. Rifaioğlu, M.N., Şahin Güçhan, N., (2008), “Understanding and Preserving the Spirit of Place by an Integrated Methodology in Historic Urban Contexts", 16th General Assembly and Scientific Symposium of ICOMOS, 29 Septembre-4 October, Quebec City, CANADA. (electronic publication please see http://www.international. icomos.org/quebec208/cd/papers all az.html).

21. Rossi, A., (1982), The Architecture of the City. New York: MIT Press.

22. Sharp, T., (1969), Town and Townscape, London, Murray.

23. UNESCO, (2008), Operational Guidelines for the Implementation of the World Heritage, Retrieved from http:// whc.unesco.org/archive/opguide08-en.pdf.

24. UNESCO, (2011), Recommendation on the Historic Urban Landscapes, Paris.

25. Worskett, R., (1969), The Character of Towns. London: Architectural Press.

Key words: Ownership; property rights; spirit of place; tangible and intangible values; urban conservation; urban form.

Anahtar sözcükler: Mülkiyet; mülkiyet hakları; yerin ruhu; maddi (somut) ve manevi (soyut) değerler; kentsel koruma; ketsel form. 